\title{
Da Paixão ao Crime: uma Espacialização da Violência contra as Mulheres em Rio Grande - RS1
}

\author{
From Passion to Crime: a Spacialization of Violence against Women in Rio Grande \\ - RS
}

\author{
Marilia Cardoso Lopes \\ Universidade Federal do Rio Grande - FURG \\ feliciamt@gmail.com \\ Susana Maria Veleda da Silva \\ Universidade Federal do Rio Grande - FURG \\ sucasilva@yahoo.com.br
}

\section{Resumo}

Na pesquisa enfocamos a violência de gênero a partir da Geografia feminista, em uma escala local - o município do Rio Grande (RS). A violência contra as mulheres se configura como uma das mais complexas questões a serem enfrentadas pela sociedade atualmente, nossos questionamentos buscam explicá-la a partir da caracterização e da espacialização. A metodologia utilizada consistiu no levantamento de dados na Delegacia Especializada de Atendimento à Mulher (DEAM), a partir dos boletins de ocorrências que apresentavam mulheres vítimas de parceiros ou exparceiros, tendo como recorte temporal o trimestre compreendido entre os meses de maio, junho e julho de 2010. Verificamos que, a violência de gênero está disseminada por todo o município do Rio Grande, e sua tipologia é a mais diversificada possível. Ainda que, grande parte dos registros tenha sido feita por pessoas de baixa escolaridade e por moradoras de localidades com perfil de baixa renda, não podemos inferir que a violência contra as mulheres apresente somente vítimas com essas características. É necessário considerar que com maior autonomia é mais fácil sair de uma relação violenta. Mesmo neste pequeno recorte temporal encontramos vítimas de todas as idades, cores e de diferentes níveis de escolaridade.

Palavras - chave: Violência contra as Mulheres; Espacialização; Gênero; Geografia.

\begin{abstract}
In this research, we focus on gender violence according to the perspective of feminist geography in a local scale - the city of Rio Grande (RS), Brazil. Violence against women appears as one of the most complex issues to be faced by society nowadays, and our questionings seek to explain it from the perspective of characterization and spatial distribution. The methodology used consisted of data collection in the Specialized Police Service to Women (DEAM), from police reports that showed women victims of intimate partners or former partners, in the period comprehended in the months of May, June and July 2010. We found that gender violence is widespread throughout the city of Rio Grande, and its types are the most diverse possible. Although most of the records has been made by people with low education and residents of low-income profile localities, we cannot infer that the violence against women affects only victims with these characteristics. It is necessary to consider that with a greater autonomy, it is easier to leave a violent relationship. Even in this short period analysis, we find victims of all ages, colors and different levels of learning.
\end{abstract}

Keywords: Violence against Women; Spatialization, Gender; Geography. 


\section{Introdução}

Após séculos de discriminação e de desigualdade, as mulheres ainda hoje lutam para garantir um lugar de respeito na sociedade. Embora muitos preconceitos já tenham sido superados, ainda resta muito a ser feito, principalmente quando essa distinção se traduz em violência. A violência contra as mulheres, sobretudo, a violência de gênero, é um problema social que atinge pessoas no mundo todo. Na maioria das ocorrências o agressor é o próprio companheiro da vítima e o ambiente doméstico torna-se lugar para sensações de medo e perigos constantes, gerando marcas não apenas físicas, mas também morais e psicológicas nas mulheres e na família. Pelo número de vítimas e pela magnitude de sequelas orgânicas e emocionais que produz, a violência adquiriu um caráter endêmico sendo convertida em um problema de saúde pública, em vários países (MEDEIROS, 2005). Além disso, é uma violação dos direitos humanos e envolve as áreas da segurança pública, da justiça, da educação, de diversos serviços sociais, da economia, da política, entre outras. Para Teles e Melo (2003) existe hoje um consenso entre vários setores da sociedade de que a violência deve ser pensada de forma multidisciplinar. Entretanto, ainda tem sido tratada como assunto marginal. Por entendermos que a violência contra mulher é uma questão realmente multidisciplinar, acreditamos que a Geografia também pode contribuir para analisar a questão, pois o conhecimento produzido está comprometido com as mudanças sociais, o que pode ser feito através de uma perspectiva feminista. Embora a perspectiva feminista e as questões de gênero estejam presentes na Geografia mundial há mais de trinta anos, Veleda da Silva afirma que, ainda hoje, a Geografia brasileira é tímida no que diz respeito a estas questões, porém "os estudos feministas na Geografia já se apresentam como um caminho sem volta" (VELEDA DA SILVA, 2009, p.306).

$\mathrm{Na}$ pesquisa enfocamos a violência de gênero a partir da Geografia feminista, em uma escala local - o município de Rio Grande (RS). Uma vez que a violência contra as mulheres se configura como uma das mais complexas questões a serem enfrentadas pela sociedade atualmente, nossos questionamentos buscam explicá-la a partir da caracterização e da espacialização.

Rio Grande, a cidade mais antiga do estado do Rio Grande do Sul, localizada na Planície Costeira Sul faz parte da Aglomeração Urbana do Sul. Apresenta como limite ao Norte o município de Pelotas e a Laguna dos Patos; ao Sul o município de Santa Vitória do Palmar; a Leste o Oceano Atlântico, e a Oeste os municípios de Pelotas, Arroio Grande e Lagoa Mirim. O município é composto por cinco distritos, Rio Grande é a sede do primeiro distrito. $\mathrm{O}$ segundo distrito denomina-se Ilha dos Marinheiros, o terceiro, Povo Novo; o quarto distrito, Taim e o quinto denomina-se de Quinta (figura 1). Segundo o Censo Demográfico do Instituto Brasileiro de Geografia e Estatística (IBGE, 2010), o município possui 197.253 habitantes, destes, 102.256 são mulheres e 94.997 homens.

Rio Grande possui Conselho Municipal dos Direitos da Mulher, delegacia especializada em casos de violência contra mulheres e casa-abrigo, sendo que a nível nacional foram criadas, até o momento, 463 delegacias especializadas e apenas 68 casas (LOPES, 2010). Em 2010, entrou para o ranking dos municípios gaúchos que apresentaram as maiores taxas de registros de ocorrência de crimes com vítima mulher (4,87 por $100 \mathrm{mil}$ habitantes), totalizando 4.976 ocorrências (SPM-RS, 2011).

Figura 01: municípios Rio Grande e São José do Norte: localizados no Brasil e no Estado do Rio Grande do Sul (RS).

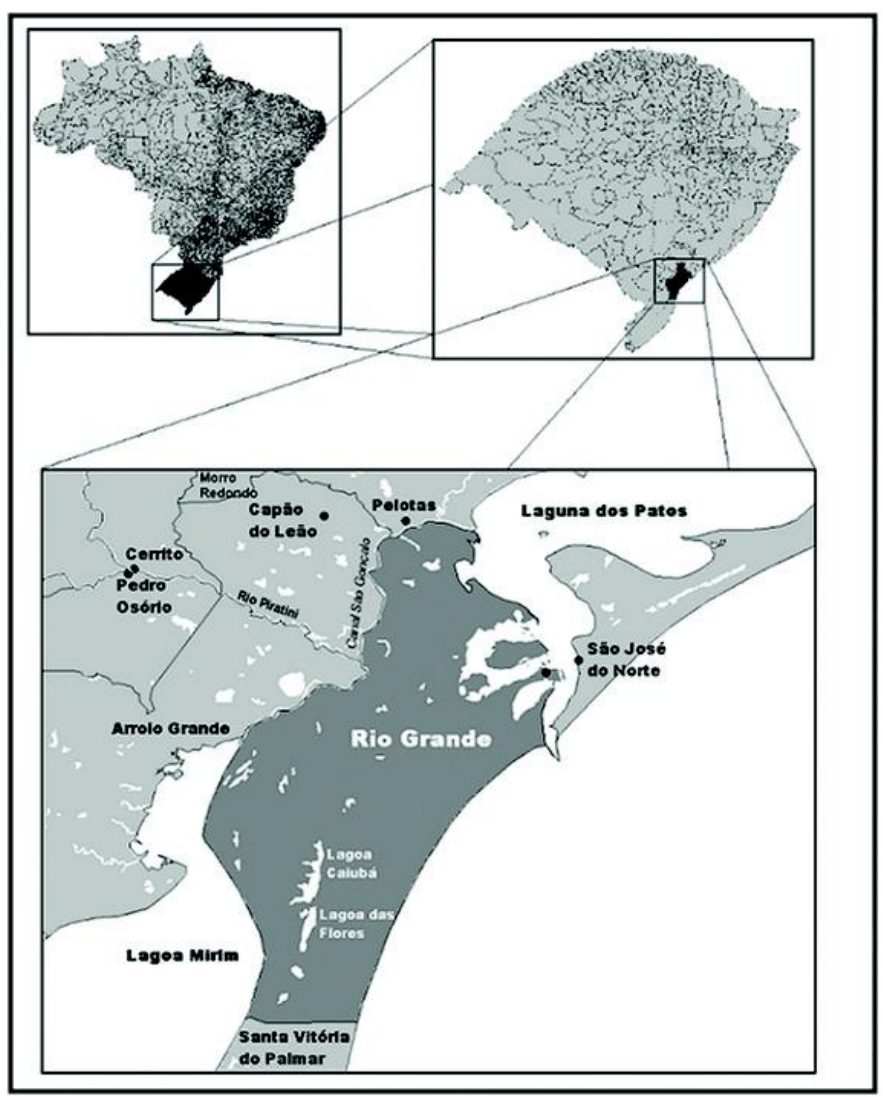

Fonte: CaderNAU, v. 1, n.1, 2007. Base Cartográfica Digital do Rio Grande do Sul (1:250.000). UFRGS, 2006. Adaptado por Edílson W. Pedroso Júnior, Geógrafo - CREA RS143232. 
Assim a fim de compreender o fenômeno da violência contra as mulheres a nível local, o objetivo principal do artigo é compreender os casos de violência doméstica em Rio Grande a partir de duas abordagens: construir uma tipologia da violência, considerando o tipo de violência, o local de moradia, a faixa etária, a cor, a ocupação e a escolaridade do casal envolvido e espacializar as denúncias de violência contra as mulheres na cidade, a partir do local de ocorrência dos crimes e do local de moradia declarados no boletim de ocorrência (BO).

A metodologia utilizada consistiu no levantamento de dados na Delegacia Especializada de Atendimento à Mulher (DEAM) a partir dos boletins de ocorrências que apresentavam mulheres vítimas de parceiros ou exparceiros, tendo como recorte temporal o trimestre compreendido entre os meses de maio, junho e julho de 2010.

$\mathrm{O}$ artigo está estruturado em três partes. $\mathrm{Na}$ primeira, tratamos das questões conceituais a cerca das diversas violências contra as mulheres e reunimos os principais elementos resultantes da articulação entre sociedade e Estado, que se transformaram em importantes instrumentos de combate a violência de gênero no Brasil. Na segunda, caracterizamos os casos de violência pesquisados e na terceira, parte espacializamos essas ocorrências, através dos bairros mencionados pelas mulheres no momento em que realizaram os registros. Por fim tecemos algumas considerações finais.

\section{Violência contra mulheres e o papel do Estado e da sociedade}

Entendemos que um dos conceitos de violência que melhor representa o enfoque adotado no artigo é o de Chauí (1985 apud AZEVEDO, 1985) que considera violência sob dois ângulos. Primeiro, enquanto conversão de uma diferença e de uma assimetria em relação hierárquica de desigualdade, com fins de dominação, de exploração e de opressão, ou seja, a transformação dos diferentes em desiguais e a desigualdade em relação entre superior e inferior. Em segundo, uma ação que transforma o ser humano não mais como sujeito, e sim como uma coisa, caracterizada pela inércia, pela passividade e pelo silêncio, de modo que quando a atividade e a fala do outro são impedidas ou anuladas, há violência.

Ainda no que tange o conceito de violência, é importante a compreensão das autoras Maria Amélia Teles e Mônica Melo (2003), que consideram o fenômeno uma forma de restringir a liberdade de uma ou mais pessoas, reprimindo e ofendendo física ou moralmente:
Violência, em seu significado mais frequente, quer dizer uso da força física, psicológica ou intelectual para obrigar outra pessoa a fazer algo que não está com vontade; é constranger, é tolher a liberdade, é incomodar, é impedir a outra pessoa de manifestar seu desejo e sua vontade, sob pena de viver gravemente ameaçada ou até mesmo ser espancada, lesionada ou morta. É um meio de coagir, de submeter outrem ao seu domínio, é uma violação dos direitos essenciais do ser humano (TELES e MELO, 2003, p.15).

Araújo et al (2004) ressaltam que a violência tem muitas caras, sendo que algumas estão disfarçadas de tradição, outras de moralidade, outras, entretanto, sem disfarce algum, mas sempre carregadas de algum tipo ou quantidade de poder que lhes permitam violentar em alguma extensão. As formas pelas quais a violência se manifesta podem ser tanto física, sexual, emocional quanto moral. Todavia, segundo Saffioti (1999) essas agressões não ocorrem isoladamente, estando a violência emocional presente em todas as outras formas de agressão.

Aliado ao conceito de violência, a definição de gênero nos ajuda a compreender melhor a violência que atinge muitas mulheres. Teles e Melo (2003) entendem gênero como uma lente de aumento que facilita a percepção das desigualdades sociais e econômicas entre mulheres e homens, que se deve à discriminação histórica sofrida pelas mulheres. Através desse instrumento é possível analisar a discriminação sexual e suas imbricações ao que diz respeito à classe social, às questões étnico-raciais, intergeracionais e de orientação sexual. As autoras enfatizam que gênero não deve ser confundido com sexo, pois o último termo faz referência a características e diferenças biológicas, sendo dadas pela natureza, enquanto o gênero engloba diferenças de cunho socioculturais existentes entre os sexos, que se traduzem em desigualdades econômicas e políticas, deixando para as mulheres um lugar de posição inferior ao dos homens. Essa prática, no entanto, não advém da natureza, e sim de um processo consolidado ao longo da história, e reforçado pelo patriarcado e pela ideologia, que coloca o homem em posição de dominação e a mulher de submissão.

A violência de gênero pode ser construída também nas relações entre homens e entre mulheres. Todavia, de acordo com Saffioti (2001), o fato da desigualdade entre eles não ser dada previamente ao início da relação irá diferenciá-la da relação de gênero existente 
entre homem-mulher. Dessa forma, a violência de gênero dirá respeito, na grande maioria das vezes a este último tipo de relação.

Neste artigo utilizaremos o conceito de violência de gênero concebido por Saffioti:

Violência de gênero é um conceito amplo, abrangendo vítimas como mulheres, crianças e adolescentes de ambos os sexos. No exercício da função patriarcal, os homens detêm o poder de determinar a conduta das categorias sociais nomeadas, recebendo autorização ou, pelo menos, tolerância da sociedade para punir o que se lhes apresenta como desvio. Ainda que não haja nenhuma tentativa, por parte das vítimas potenciais, de trilhar caminhos diversos do prescrito pelas normas sociais, a execução do projeto de dominação exploração da categoria social homens exige que sua capacidade de mando seja auxiliada pela violência. Com efeito, a ideologia de gênero é insuficiente para garantir a obediência das vítimas potenciais aos ditames do patriarca, tendo este necessidade de fazer uso da violência. Nada impede, embora seja inusitado, que uma mulher pratique violência física contra seu marido/companheiro/namorado. As mulheres como categoria social não tem, contudo, um projeto de dominação exploração dos homens. $\mathrm{E}$ isto faz uma gigantesca diferença (SAFFIOTI, 2001, p.115).

Assim, podemos dizer que a ordem patriarcal é um fator preponderante na produção da violência de gênero, pois está na base das representações de gênero que legitimam a dominação masculina internalizada por homens e por mulheres (ARAÚJO; MARTINS e SANTOS, 2004).

Segundo Teles et al (2003) a prática da violência de gênero é transmitida de geração a geração tanto por homens como por mulheres e tem sido o primeiro tipo de violência em que o ser humano é colocado em contato de maneira direta. Ela foi perpetuada por tanto tempo no âmbito das relações humanas que é vista como natural, como se fizesse parte da natureza humana.

Saffioti (1999, p.83) ressalta que, especialmente em se tratando de violência de gênero, e mais especificamente intrafamiliar e doméstica "são muito tênues os limites entre quebra de integridade e obrigação de suportar o destino de gênero traçado para as mulheres: sujeição aos homens, sejam pais ou maridos”. Dessa forma:

Compreendida na violência de gênero, a violência familiar - aquela que envolve membros de uma mesma família extensa ou nuclear, levando-se em conta a consanguinidade e a afinidade - pode ocorrer no interior do domicílio ou fora dele, embora seja mais frequente o primeiro caso. A violência doméstica tem lugar, predominantemente, no interior do domicílio. Nada impede o homem, contudo, de esperar sua companheira à porta de seu trabalho e surrá-la exemplarmente diante de todos os seus colegas por se sentir ultrajado com sua atividade extra-lar (SAFFIOTI, 1999, p.83).

De acordo com Teles et al (2003) apesar da origem dos conceitos de violência doméstica e de violência intrafamiliar serem distintos, tendo em vista que aquele nasce com o movimento feminista, que denuncia o quanto ambiente doméstico é perigoso para as mulheres, pois são as mais atingidas pela violência no espaço privado, as ideias de ambos são bastante semelhantes, uma vez que a violência intrafamiliar ocorre com frequência no âmbito doméstico. Ambas as denominações são utilizadas com frequência para tratar de casos de violência contra as mulheres e grande parte das vezes, irão se referir a agressão física, psicológica ou moral sofrida pelas mulheres por parte de seus companheiros/ex-companheiros afetivos.

Desde a década de 1970, o movimento de mulheres e feminista trabalha para dar visibilidade a este tema. Em 1975 o slogan 'Quem ama não mata' ganhou as ruas, quando muitas mulheres foram protestar contra as absolvições de maridos que haviam assassinado suas esposas 'em defesa da honra'. Quase uma década depois, em 1984, o Brasil assinou a Convenção sobre a Eliminação de Todas as Formas de Discriminação contra a Mulher, o primeiro instrumento internacional de direitos humanos voltado especialmente para a proteção das mulheres. A campanha nacional, que tomou conta das agendas dos movimentos de mulheres da segunda metade da década de 1980, mobilizou a opinião pública para defender uma Constituição democrática que reconhecesse seus direitos. A ação do Conselho Nacional de Direitos das Mulheres (criado em 1985) e entidades populares, sindicais e demais conselhos propiciaram conquistas históricas, dentre as quais a desmistificação da figura do chefe da sociedade conjugal e o reconhecimento da igualdade de direitos entre mulheres e homens no casamento, a licença maternidade de 120 dias e a licença-paternidade. A 
Constituição Federal de 1988 inovou ao reconhecer a necessidade do Estado de coibir a violência familiar (TELES e MELO, 2003, p.102), evidenciada através do art. 226, parágrafo $8^{\circ}$ : “O Estado assegurará à família na pessoa de cada um dos que a integram, criando mecanismos para coibir a violência no âmbito de suas relações".

Em 1995, o Brasil ratificou a Convenção Interamericana para Prevenir, Punir e Erradicar a Violência contra as Mulheres (Convenção de Belém do Pará). Considerada um marco histórico na luta das mulheres por uma vida sem discriminação e violência, pois a partir de sua ratificação o Estado brasileiro passou a contar com dispositivo legal internacional que define e diz como se manifesta esta forma específica de violência que atinge as mulheres, pelo simples fato de serem mulheres. De acordo com a Convenção, deve ser interpretada como violência contra as mulheres, "qualquer ação ou conduta baseada no gênero, que cause morte, dano ou sofrimento físico, sexual ou psicológico à mulher, tanto no âmbito público como no privado" (AGENDE, 2004, p. 9). Superar a dicotomia entre o público e o privado, por certo, foi uma grande contribuição dessa definição, uma vez que reconhece a importância que é erradicar a violência que existe dentro do ambiente doméstico.

Em 2002, o então Presidente Luiz Inácio Lula da Silva, assumiu o compromisso de combater a violência contra as Mulheres e criou a Secretaria de Estado dos Direitos da Mulher (SEDIM), que em 2003 foi transformada em Secretaria Especial de Políticas para as Mulheres (SPM). A Secretaria é uma instância governamental que, junto com o Conselho Nacional dos Direitos das Mulheres promove programas de erradicação da violência com base no gênero. Dentre as principais conquistas está a implementação do 'Ligue 180', a Central de Atendimento à Mulher, um serviço do governo federal que tem como objetivo orientar e auxiliar as mulheres em situação de violência, oferecendo um serviço especializado, no qual as atendentes são capacitadas em questões de gênero, legislação e políticas governamentais voltadas às mulheres (SPM, 2006). Presta, especialmente, um serviço de esclarecimento às mulheres. No ano de 2008, das 269.977 ligações recebidas pela central, $52,1 \%$ eram para pedir informações. Dentre as dúvidas, $83,5 \%$ eram sobre violência doméstica e familiar, $11 \%$ referentes a crimes contra a mulher, $5,1 \%$ sobre os direitos da mulher e $0,3 \%$ queriam informações gerais. Em 2009, o número de ligações registradas foi de 401.729 .

Encaminhado em 25 de novembro de 2004, Dia Internacional pelo Fim da Violência contra as Mulheres, ao Congresso Nacional, o Projeto de Lei
4.559/2004 estabelecia a prevenção, punição e erradicação da violência doméstica e familiar contra as mulheres, e criava diretrizes para a política nacional de enfrentamento desta violência. Além disso, previa novos procedimentos policiais e processuais e a criação de Juizados de Violência Doméstica e Familiar contra a Mulher. Devido à grande mobilização popular e de vários segmentos da sociedade, o projeto consegue aprovação em todas as instâncias por unanimidade e no dia 7 de agosto de 2006 o presidente Luiz Inácio Lula da Silva assina a Lei 11.340/2006, Lei Maria da Penha ${ }^{2}$, que entrou em vigor em 22 de setembro do mesmo ano.

A Lei Maria da Penha (LMP) é hoje o principal instrumento de combate a violência doméstica e familiar contra a mulher. Dentre as muitas inovações trazidas pela lei destacamos: a proibição das penas pecuniárias; a proibição da entrega da intimação pela mulher ao agressor e a possibilidade de prisão preventiva do agressor quando houver riscos à integridade física ou psicológica da mulher. A Lei também prevê que a renúncia da denúncia ocorrerá apenas perante o juiz. Além disso, permite ao juiz conceder, no prazo de 48 horas, medidas protetivas de urgência, entre as quais estão o afastamento do agressor do lar, a suspensão do porte de armas do mesmo e o distanciamento da vítima. Os casos que envolverem questões familiares serão apreciados pelo juiz do Juizado Específico de Violência Doméstica e Familiar Contra a Mulher, o qual também tem sua criação prevista pela lei. Outro ponto que merece destaque previsto na LMP é a criação de um Sistema Nacional de Dados e Estatísticas sobre a Violência Doméstica e Familiar contra a Mulher.

$\mathrm{O}$ Pacto Nacional pelo Enfrentamento à Violência Contra a Mulher, lançado em agosto de 2007 pelo Governo Federal, é outra importante ferramenta nesse combate. Tal mecanismo consiste num acordo federativo visando o planejamento de ações que consolidem a Política Nacional de Enfrentamento à Violência Contra as Mulheres, com políticas públicas integradas em todo Brasil, dentre as prioridades a efetivação da Lei Maria da Penha.

As ações descritas acima se consubstanciam na escala local. Entendemos que a violência contra mulheres deve ser compreendida a partir de sua expressão no cotidiano que se diferencia também a partir de sua localização. Assim reafirmamos a importância do trabalho empírico na Geografia e dos estudos na escala local como elementos necessários para alavancar possibilidades de acabar com as desigualdades sociais e com todas as formas de violência. 


\section{Uma tipologia da violência contra as mulheres}

Os resultados apresentados no artigo foram obtidos através dos boletins de ocorrência (BO's) registrados nos meses de maio, junho e julho de $2010^{3}$, efetuados na Delegacia Especializada de Atendimento à Mulher (DEAM) de Rio Grande. Os dados foram coletados através de um questionário estruturado que posteriormente possibilitou a elaboração de um banco de dados dos crimes registrados. Foram consultadas todas as denúncias de crimes em que a mulher era vítima do período, porém utilizamos somente os 170 registros que envolveram casais, em que mulher é vítima do companheiro ou ex-companheiro afetivo.

\section{A violência contra as mulheres em números}

Dentre as 170 ocorrências coletadas, foram observados os mais diversos tipos de crimes (gráfico 1), entretanto, os mais frequentes são os de ameaça e lesão corporal. Em grande parte das ocorrências havia mais de um crime sendo comunicado, dessa forma, entendemos que o número de crimes possa ser ao menos duas vezes maior do que o de registros.

Embora não estejam ilustrados no gráfico 1, alguns crimes envolveram não apenas a companheira/ex- companheira como vítima da ação. Encontramos casos em que, além de cometerem violência contra suas mulheres, os acusados agrediram fisicamente os próprios filhos, amigos e até mesmo os atuais companheiros da vítima. Em casos como estes, consideramos apenas a agressão sofrida pela mulher a fim de não fugir ao foco principal do trabalho.

Em relação ao tempo que as vítimas levam até registrar a ocorrência (gráfico 2) verificamos que 79\% das vítimas efetuaram o registro em até 24 horas do fato, sendo que $31 \%$ das mulheres realizaram o registro em até duas horas. Entretanto, existem situações que levam dias, semanas e até mesmo meses para serem levadas ao conhecimento de algum órgão policial.

Os crimes acima mencionados ocorreram principalmente no início da noite $(43 \%)$, período compreendido entre as $18 \mathrm{~h} 01 \mathrm{~min}$ e as $00 \mathrm{~h}$. O intervalo de tempo no qual os delitos ocorreram com menos frequência é logo após aquele com maior número de registros: ao longo da noite e início da manhã, compreendido entre as $00 \mathrm{~h} 01 \mathrm{~min}$ e as $06 \mathrm{~h}$.

Podemos perceber que esse tipo de violência contra as mulheres está deixando de acontecer apenas no âmbito familiar. No período estudado observamos que $25 \%$ das ocorrências ocorreram em via pública. Hospitais, escolas, estabelecimentos comerciais, locais de trabalho, casas noturnas, praças públicas, rodovias e

Gráfico 1 - Tipos de crimes registrados no trimestre ( $\mathrm{n}^{\mathrm{o}}$ absoluto)

\section{Tipos de Crime}

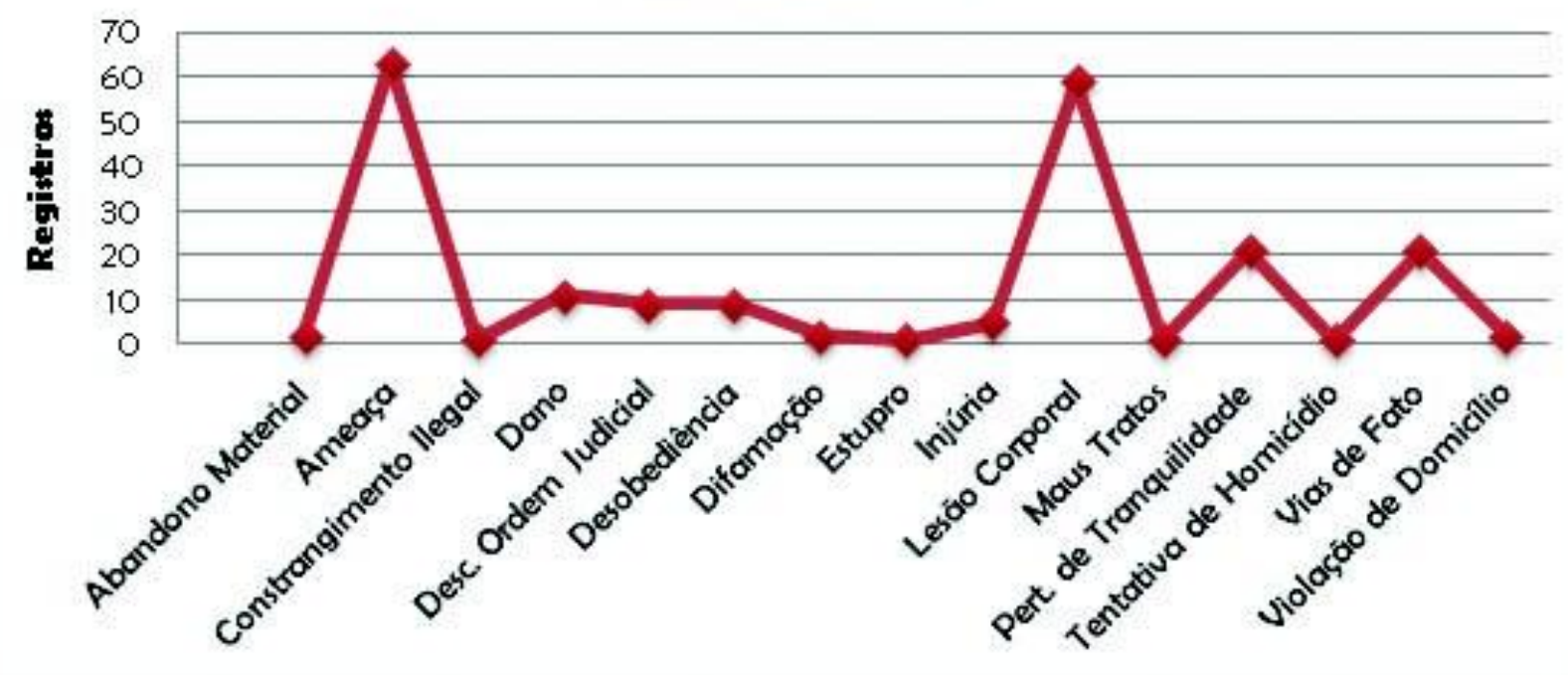

Fonte: Boletins de ocorrência da Delegacia Especializada de Atendimento à Mulher, Rio Grande, Mai/Jun/Jul 2010. Elaborado pela autora. 
Gráfico 2 - Período de tempo (horas e dias) que a vítima leva até registrar a denúncia (\%)

\section{Tempo até a denúncia}

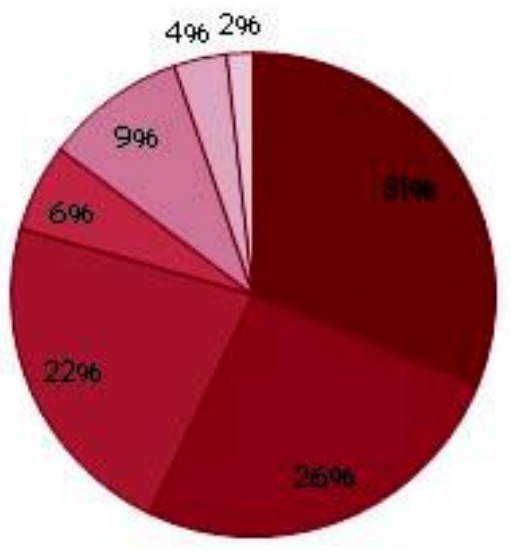

até 2 hs

A A té 6 hs

anté 24hs

口A té 48 hs

$\square$ Áté 7 dias

口A té 30 dias

口Mais de 30 dias

Fonte: Boletins de ocorrência da Delegacia Especialızada de Atendimento à Mulher, Rio Grande, Mai/Jun/Jul - 2010. Elaborado pela autora.

Gráfico 3 - Faixas etárias da vítima e do acusado (no absoluto)

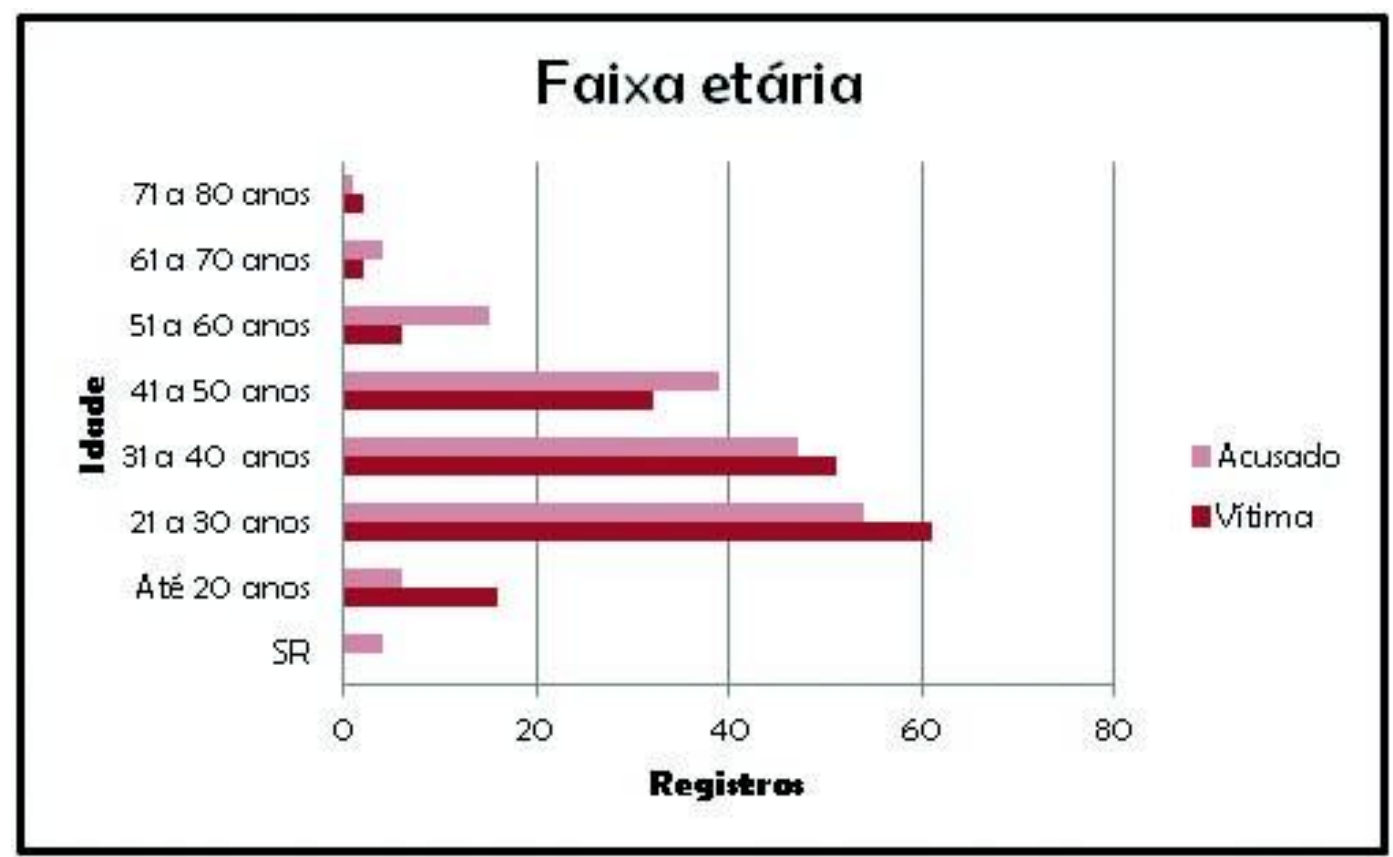

Fonte: Boletins de ocorrência da Delegacia Especializada de Atendimento à Mulher, Rio Grande, Mai/Jun/Jul - 2010. Elaborado pela autora.

casa de amigos serviram de palco para agressões físicas e psicológicas contra as mulheres nesse trimestre. Quanto ao perfil dos envolvidos nos crimes de violência contra as mulheres podemos perceber que as mulheres se tornam vítimas desde muito cedo e que, se nada é feito, assim continuam ao longo da vida, chegando inclusive a terceira idade. Ao verificar a faixa etária da vítima e do acusado (Gráfico três) 
percebemos que a maioria possui entre 21 e 30 anos, ou seja, esses crimes estão ocorrendo principalmente entre os jovens adultos. O trimestre ainda apresenta um elevado número de comunicantes bem jovens, com até os 20 anos, o que justifica o fato de, em alguns casos, o registro ter sido feito na presença da mãe. Outro dado interessante é que em $65,8 \%$ dos casos a mulher tem idade inferior a do homem.

Quanto ao tempo de relacionamento existente entre os envolvidos, verificamos que em $18 \%$ dos casos a união existia há pelo menos um ano e tinha no máximo cinco. Em 19\% das relações os envolvidos estavam juntos há pelo menos 11 anos. Nesses casos, frequentemente relatam que a situação de violência existe há muitos anos e afirmam querer dar um basta tanto nas agressões quanto no relacionamento. Para Azevedo (1985) a explicação mais plausível para a violência ocorrer com mais frequência entre os mais jovens é que estas uniões são recentes e enfrentam passagens mais críticas na trajetória de vida em comum como o estudo, a inserção no mercado de trabalho e o nascimento dos filhos. Infelizmente, $46 \%$ dos boletins não mencionavam esta informação.

Com relação ao estado civil (gráfico 4), solteira(o) é o que mais foi comunicado. De acordo com esses dados, apenas $35,3 \%$ das mulheres vítimas de agressão caracterizariam uma "união estável", declarando-se como "casadas" e "amigadas". Dentre os registros, havia casos em que o casal estava junto há apenas três meses.

Segundo informações que coletamos em cada boletim, verificamos que em $66 \%$ das ocorrências a relação já havia terminado, ou a vítima manifestou ou já havia manifestado que não queria mais viver com o acusado. O Ibope e Instituto Avon (2009), pesquisou sobre as causas que levam as mulheres brasileiras a manter uma relação conjugal: $24 \%$ responderam que falta de condições econômicas para viver sem o agressor, $23 \%$ por preocupação com a criação dos filhos, $17 \%$ por medo de ser morta caso termine a relação, 12\% acham que é falta de autoestima, $8 \%$ por vergonha de admitir que é agredida, 6\% vergonha de se separar, $4 \%$ por dependência afetiva e $4 \%$ por achar que tem obrigação de manter o relacionamento.

Em relação à cor da pele (gráfico 5) verificamos que a violência no período analisado esteve presente, principalmente, entre as pessoas de cor branca, que representam $80 \%$ das vítimas e $77 \%$ dos agressores. Foram $11 \%$ de registros de vítimas e $13 \%$ de acusados de cor preta. Os envolvidos de cor parda somam, ao todo, $14 \%$.

Quanto ao lugar de nascimento dos envolvidos verificamos que $69 \%$ dos acusados e $73 \%$ vítimas eram naturais de Rio Grande-RS. Também encontramos registros de naturais das regiões Sudeste, Nordeste e Centro-Oeste do Brasil, dos estados de Santa Catarina e Paraná, assim como de outros municípios gaúchos. Em um dos casos o acusado apresentava nacionalidade distinta. Por vezes percebermos que ambos eram oriundos de outra localidade. Este fato pode estar associado a uma maior vulnerabilidade das mulheres em relação aos agressores, tendo em vista a possibilidade de estarem longe de amigos e familiares que possivelmente iriam auxiliá-las a sair de uma relação conflituosa.

A violência tem sido denunciada por mulheres com

Gráfico 4 - Estado civil dos envolvidos ( $n^{\circ}$ absoluto $)^{4}$

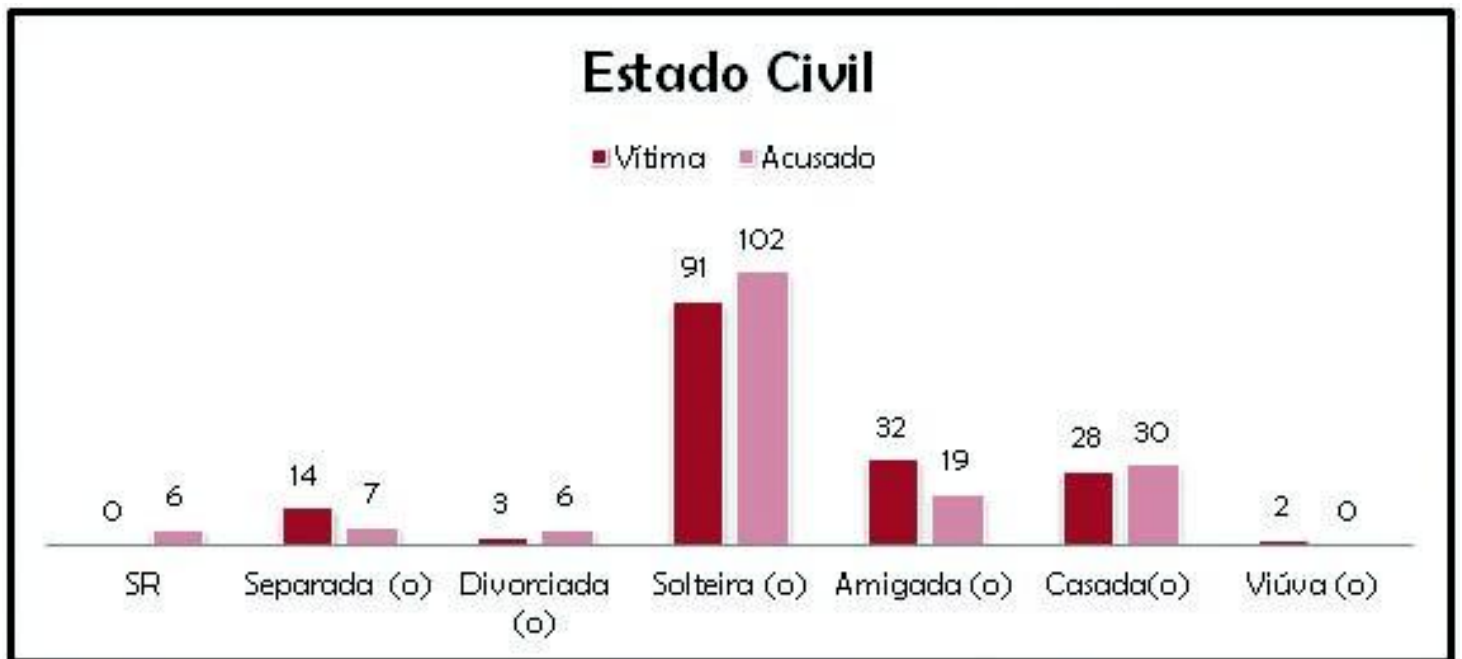

Fonte: Boletins de ocorrência da Delegacia Especializada de Atendimento à Mulher, Rio Grande, Mai/Jun/Jul - 2010. Elaborado pela autora. 
Gráfico 5 - Cor da pele dos envolvidos ( $\mathrm{n}^{\mathrm{o}}$ absoluto $)^{5}{ }^{6}$

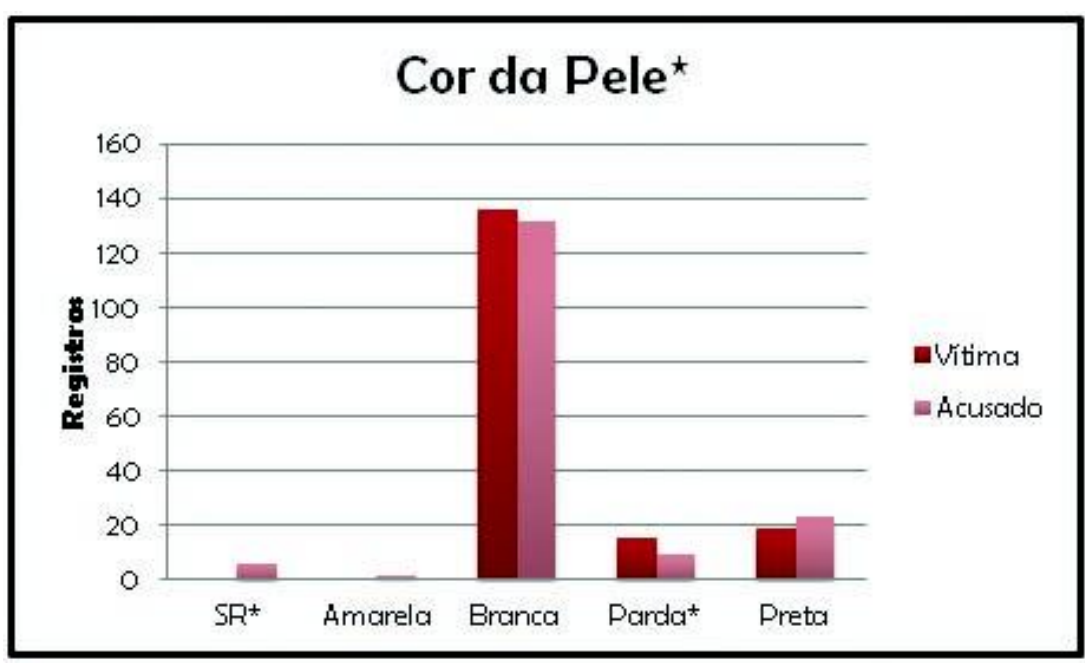

Fonte: Boletins de ocorrência da Delegacia Especializada de Atendimento à Mulher, Rio Grande, Mai/Jun/Jul - 2010. Elaborado pela autora.

Gráfico 6 - Grau de escolaridade dos envolvidos ${ }^{7}$

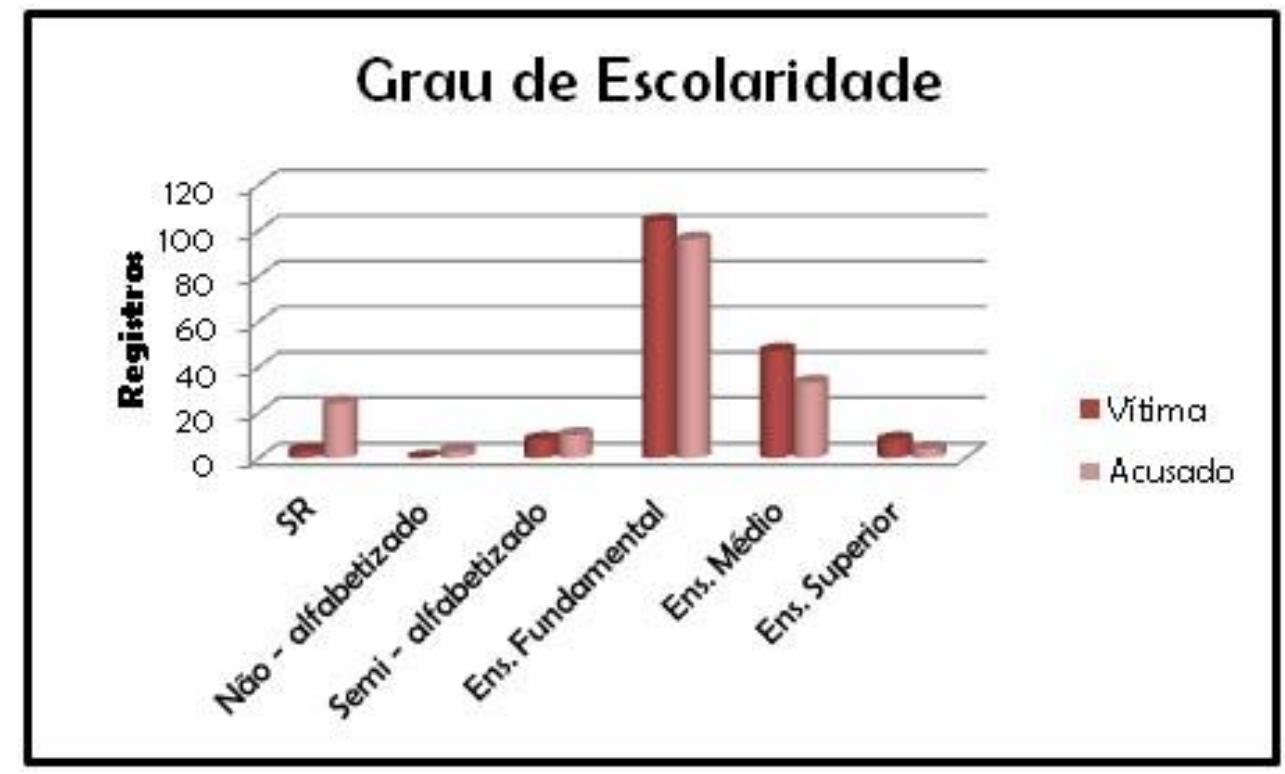

Fonte: Boletins de ocorrência da Delegacia Especializada de Atendimento à Mulher, Rio Grande, Mai/Jun/Jul - 2010. Elaborado pela autora.

os mais variados níveis de escolaridade (gráfico 6). Todavia, as vítimas que mais tem denunciado são as que possuem o ensino fundamental (61\%). Também constatamos que os agressores, na maioria dos casos, possuem grau de escolaridade inferior às suas vítimas.

Quanto às ocupações registradas, tanto das vítimas quanto dos agressores, no trimestre em estudo podemos perceber diversas ocupações: telefonista, carteira, assistente social, técnico de contabilidade, servente, taxista, bancária, entre outras. Parte dos registros não continha informações neste item. Segundo Azevedo (1985), o fato de em algumas relações a mulher ter maior escolaridade ou um emprego que tenha mais status que o do marido poderia contribuir para que houvesse violência entre o casal. Pois este tipo de arranjo familiar subverteria a família patriarcal tradicional e colocaria em xeque o status quo do homem como principal provedor. Assim, o homem usaria a violência como uma forma de impedir a 'subversão da ordem', de garantir que as 
coisas 'ficassem em seu lugar'.

Dos registros que mencionavam filhos, $19 \%$ das vítimas afirmaram ter ao menos um filho ou estar grávida do acusado. Por outro lado, $9 \%$ das comunicantes disseram não ter filhos com o agressor.

Ao realizarem a denúncia, $24 \%$ das vítimas relataram que já haviam feito registros anteriores contra o mesmo acusado. Em relação à solicitação de medidas protetivas, previstas na Lei 11.340/2006, 55\% das mulheres optaram por solicitar as medidas de direito e $15 \%$ já haviam solicitado em outros registros. Dentre os motivos alegados pelas vítimas que não pediram proteção estão a preservação dos filhos, a intenção de sair de casa, a falta de informações sobre o atual paradeiro do acusado ou do seu local de trabalho e o medo de prejudicar profissionalmente o agressor. Com relação à vontade de representar criminalmente contra o agressor, $85 \%$ das comunicantes responderam positivamente.

Em 26\% dos registros as comunicantes mencionaram que os agressores eram dependentes de álcool ou entorpecentes, principalmente crack, sendo que em alguns casos o acusado era dependente de ambos.

Informações quanto à condição física da vítima na hora da declaração também foram coletadas. Em 18\% dos registros, a vítima foi classificada como ferida, em $1 \%$ como medicada - quando a própria Brigada Militar encaminhou a vítima ao Pronto Socorro da Santa Casa - e em $80 \%$ dos registros foram consideradas normais fisicamente, não aparentando lesões.

$\mathrm{O}$ ciúme excessivo do acusado, a desconfiança de traição, a não aceitação do término do relacionamento, as questões envolvendo pensão, a visita aos filhos e, discussões que podem ser consideradas banais (como não ter diminuído o volume da televisão quando o acusado mandou ou ter dito que não faria), figuram entre as motivações que levaram o acusado a agir.

Alguns crimes mencionados anteriormente utilizaram como instrumento: faca, pedaço de pau, barra de ferro, bengala, bicicleta, tijolo, adaga e arma de fogo. Segundo Teles e Melo (2003) a violência de gênero é praticada pelo homem para dominar a mulher e não eliminá-la fisicamente. Mesmo neste pequeno recorte de tempo - maio, junho e julho de 2010 - foi possível constatar isso em casos concretos. Através de alguns relatos conseguimos absorver a magnitude da violência que algumas mulheres sofreram. Consideremos como se sente uma mulher que teve o cabelo cortado pelo companheiro; que teve os dentes arrancados por um soco do marido; que tem diversos hematomas, pois o companheiro chutou-lhe o corpo inteiro; que vive atormentada, em casa, no trabalho e na rua por um ex-companheiro com o qual ela decidiu não viver mais; que é agredida física e verbalmente quando veste algo que não agrada o companheiro, ou ainda, é acusada injustamente de traição? Para Teles e Melo, a intenção masculina é possuir a mulher, tê-la como sua propriedade, determinar o que ela deve desejar pensar, vestir. "(...) ele quer tê-la sob seu controle e ela deve desejar somente a ele próprio" (TELES e MELO, 2003, p.25) o que significaria negar a si mesma.

\section{A espacialização da violência contra as mulheres}

Para espacializar a violência contra mulheres na cidade do Rio Grande utilizamos a Malha Municipal Digital de $2000^{8}$ no formato shape disponibilizada pelo Instituto Brasileiro de Geografia e Estatística (IBGE), que divide a cidade através de setores censitários ${ }^{9}$.

Agrupamos os diversos setores em 18 grandes áreas (figura 3), tendo como objetivo unir os setores

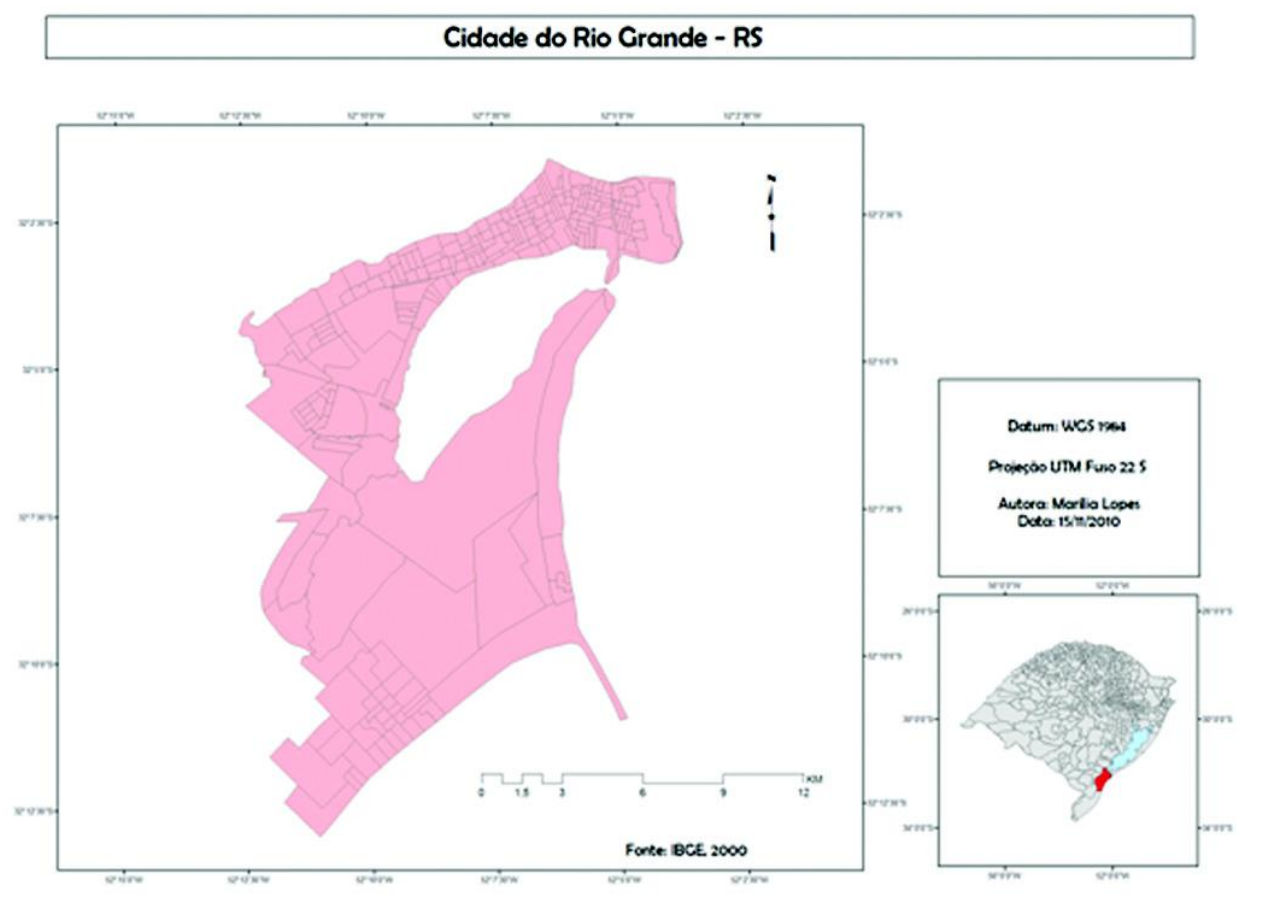


censitários próximos e homogêneos ${ }^{10}$ para que fosse possível encontrar nessas áreas os bairros mencionados pelas vítimas no momento da denúncia, o que se tornaria inviável caso continuássemos trabalhando com os setores censitários.

O Quadro 1 relaciona o local de ocorrência do delito e o local de residência da vítima, de acordo com os bairros (como popularmente são conhecidos) e mencionados no registro policial.

Optamos por realizar duas espacializações, uma destacando o índice de violência de acordo com os

Figura 3

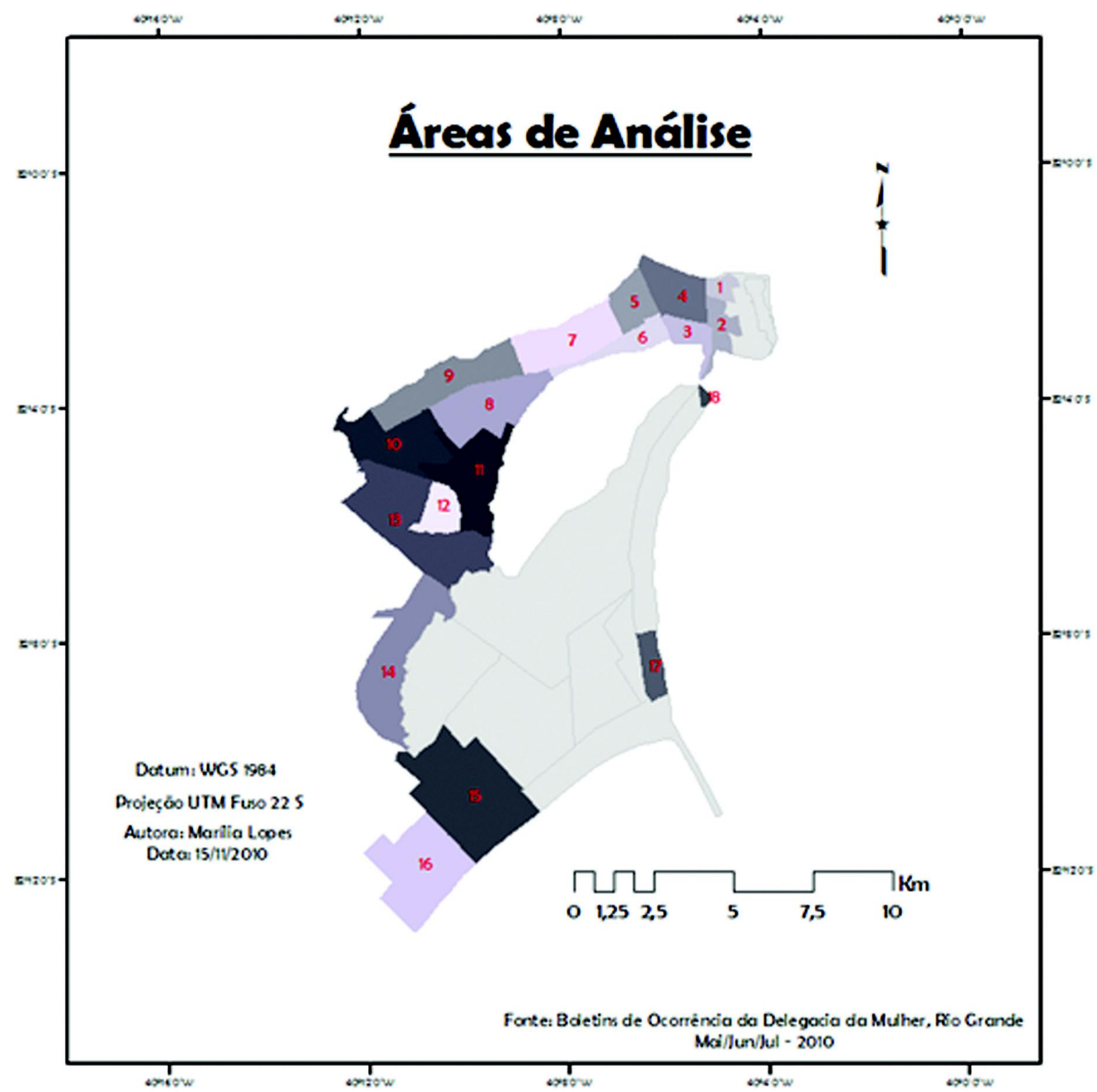


Da Paixão ao Crime: uma Espacialização da

Violência contra as Mulheres em Rio Grande - RS

Quadro 1 - Ocorrências por Área (nº absolutos)

\begin{tabular}{|c|c|c|c|}
\hline Áreas & Bairros & Por Local do Crime & Por Local de Residência \\
\hline \multirow[b]{2}{*}{ Não Espacializados } & Fora das áreas & 6 & 6 \\
\hline & Sem local específico & 8 & 0 \\
\hline Área 1 & Vila Militar & 0 & 1 \\
\hline \multirow[b]{2}{*}{ Área 2} & Getúlio Vargas & 23 & 22 \\
\hline & Santa Tereza & 1 & 1 \\
\hline \multirow{3}{*}{ Área 3} & Lar Gaúcho & 3 & 1 \\
\hline & Navegantes & 2 & 1 \\
\hline & Salgado Filho & 1 & 1 \\
\hline Área 4 & Centro & 21 & 11 \\
\hline \multirow[t]{2}{*}{ Área 5} & Vila São Paulo & 0 & 2 \\
\hline & Cidade Nova & 11 & 13 \\
\hline \multirow[t]{2}{*}{ Área 6} & Dom Bosquinho & 1 & 2 \\
\hline & Parque & 2 & 2 \\
\hline \multirow{8}{*}{ Área 7} & Miguel C. Moreira & 2 & 0 \\
\hline & Municipal & 2 & 2 \\
\hline & Rural & 7 & 6 \\
\hline & Buchholz & 4 & 7 \\
\hline & Hidráulica & 4 & 4 \\
\hline & Lagoa & 1 & 1 \\
\hline & Junção & 1 & 1 \\
\hline & América & 2 & 2 \\
\hline \multirow{4}{*}{ Área 8} & Parque Coelho & 1 & 3 \\
\hline & Vila Maria & 1 & 1 \\
\hline & Marluz & 2 & 3 \\
\hline & Cibrazem & 1 & 2 \\
\hline \multirow{6}{*}{ Área 9} & São João & 5 & 5 \\
\hline & São Miguel & 11 & 12 \\
\hline & Prado & 1 & 2 \\
\hline & Profilurb & 3 & 4 \\
\hline & Profilurb II/ S. R. de Cássia & 1 & 1 \\
\hline & N. S. de Fátima & 1 & 1 \\
\hline \multirow{5}{*}{ Área 10} & Castelo Branco & 3 & 3 \\
\hline & Cohab IV & 0 & 3 \\
\hline & Santa Rosa & 1 & 1 \\
\hline & Cidade de Águeda & 9 & 9 \\
\hline & Trevo & 4 & 4 \\
\hline
\end{tabular}




\begin{tabular}{|c|c|c|c|}
\hline \multirow{2}{*}{ Área 11 } & Vila Maria José & 1 & 1 \\
\hline & Jardim Humaitá & 0 & 1 \\
\hline & $\begin{array}{c}\text { São Jorge/Parque } \\
\text { Universitário }\end{array}$ & 2 & 3 \\
\hline Área 12 & Jardim do Sol & 1 & 2 \\
\hline Área 13 & Parque Marinha & 5 & 6 \\
\hline Área 14 & Parque São Pedro & 1 & 4 \\
\hline Área 15 & Senandes & 0 & 0 \\
\hline Área 16 & Bolaxa & 0 & 0 \\
\hline Área 17 & Cassino & 4 & 4 \\
\hline Área 18 & Parque Guanabara & 1 & 1 \\
\hline
\end{tabular}

Fonte: Boletins de ocorrência da Delegacia Especializada de Atendimento à Mulher, Rio Grande, Mai/Jun/Jul - 2010. Elaborado pela autora.

locais nos quais os crimes se efetuaram (figura 4), ou seja, os registros foram inseridos na área em que ocorreram e outra, com o índice de violência segundo o bairro no qual a vítima reside (figura 5), aqui a área em que foi inserido os dados de violência é aquela na qual a comunicante declara no ato da denúncia. Nas duas espacializações não estarão incluídos os registros que ocorreram fora da área urbana da sede da cidade do Rio Grande. No trimestre encontramos registros de moradoras do Taim, da Vila da Quinta, Povo Novo e Ilha da Torotama. Na primeira espacialização quatorze ocorrências não estão incluídas, seis por localizarem-se fora do perímetro trabalhado e outras oito por representarem crimes que ocorreram via celular, por meio de amigos, no local de trabalho ou de alguma outra maneira que não possibilitou localizá-los no espaço. $\mathrm{Na}$ outra espacialização, por residências das vítimas, apenas não estarão as seis ocorrências de fora da área selecionada para a análise.

Elaboramos um índice de violência no qual classificamos as áreas que apresentaram de zero a cinco ocorrências como de baixo índice, as que continham de seis a 10 de índice médio; de 11 a 20 alto índice e acima de 20 com índice de violência muito alto.

As áreas 2, 4, 7 e 9 foram os locais onde os crimes mais ocorreram, apresentando, dessa forma, um alto índice de violência. As áreas 2 e 4 , situadas próximas à DEAM, podem indicar que o índice elevado se deve a essa proximidade, sendo um facilitador para que os registros tenham sido feitos. Já com as áreas mais afastadas, como as de número $14,15,16$ e 17, pode ter ocorrido o inverso, contribuíram para que alguns crimes não tenham sidos registrados, já que as vítimas, em alguns casos, dependem de ônibus, por exemplo, para se deslocar até a Delegacia. Entretanto, acreditamos que este fator não influência de forma significativa a decisão das vítimas em denunciar ou não o agressor.

As maiores vítimas de violência no trimestre são as moradoras das áreas 2,7 e 9 . Através da comparação das figuras acima, podemos perceber o caráter público de boa parte dos crimes, que ocorreram, muitas vezes, no Centro da cidade (21), porém suas vítimas não residem neste local (11), ou seja, o crime provavelmente tenha ocorrido na rua, já que a área central da cidade apresenta diversos espaços de acesso público.

É importante ressaltar que alguns bairros compreendidos dentro dessas grandes áreas tiveram um número significativo de registros, como é o caso da área 2, na qual o bairro conhecido como Getúlio Vargas aparece com 22 ocorrências, enquanto o bairro Santa Tereza com uma. Na área 7 , os registros estão mais distribuídos entre os bairros, todavia os bairros Buchholz (7) e Rural (6), foram os que apresentaram maior índice de violência. O bairro São Miguel, na Área 9 influenciou significativamente no índice apresentado na área, pois enquanto este bairro apresentou 12 casos de violência, o segundo bairro com mais ocorrências (São João) apresentou 5. O mesmo fenômeno ocorre na área 10 , onde o bairro Cidade de Águeda (9) apresentou mais denúncias do que os outros três bairros que compõem a unidade: 
Castelo Branco (3), Cohab IV (3) e Santa Rosa (1).

As áreas 1 e 12 foram mantidas separadas das áreas próximas por apresentarem em sua maior parte, renda média do responsável - sempre superior a R\$ 699,00 bastante diferenciada das áreas vizinhas. A área 1 é composta predominantemente pelo bairro Vila Militar (1), conhecido por abrigar vários profissionais da área de segurança, com renda média do responsável chegando a $\mathrm{R} \$ 1.615,00$. A área 12 localiza-se o bairro
Jardim do Sol (2), aonde a renda média dos responsáveis dos setores chega a R\$ 3.218,00. Tendo em vista que optamos por agrupar os setores censitários mais próximos, sem interferência de limites naturais, e o mais homogêneo possível, acreditamos que seria melhor analisá-los isoladamente para um resultado mais próximo à realidade.

\section{Algumas Reflexões}

Figura 4

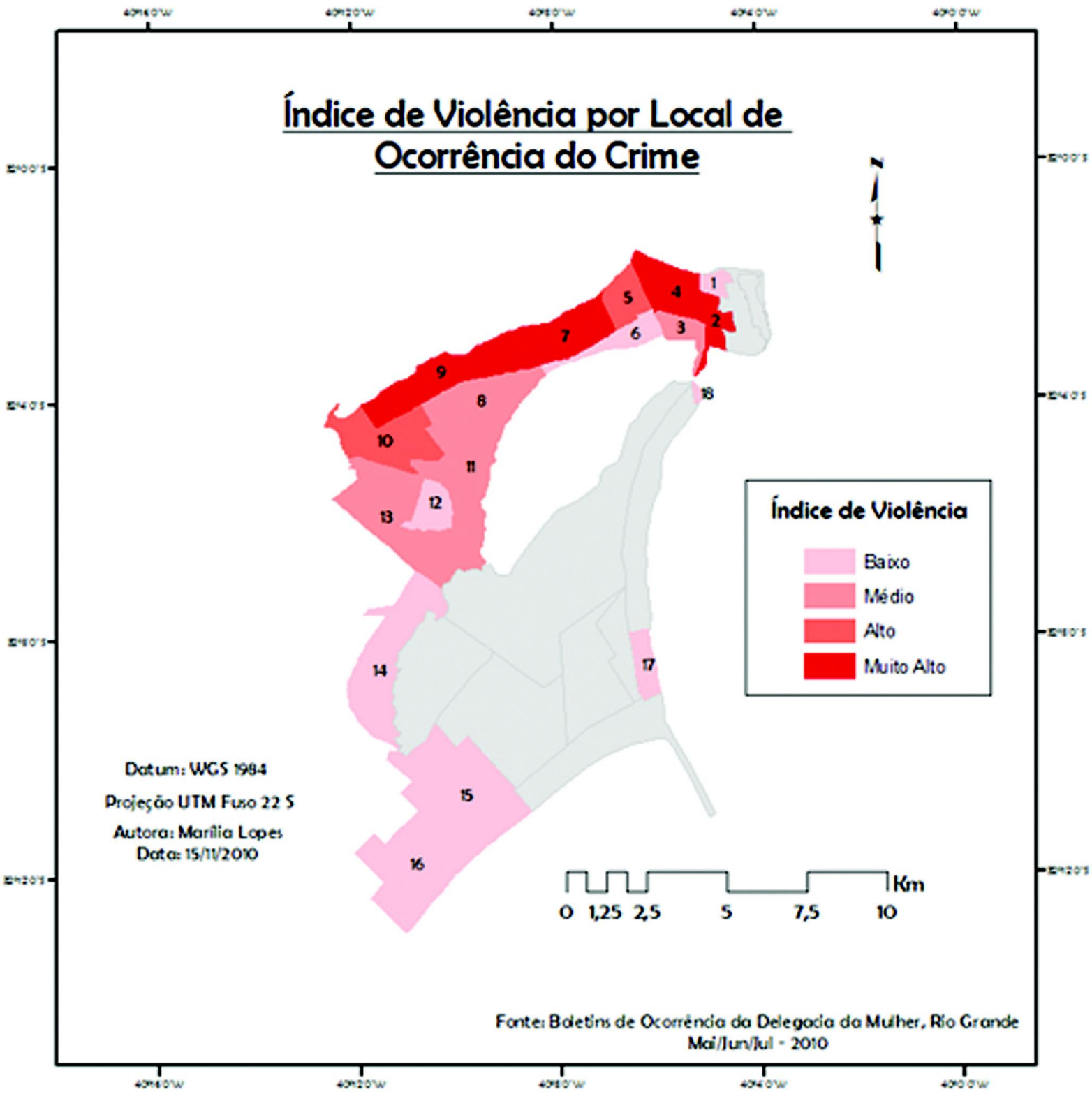

Marilia Cardoso Lopes e Susana Maria Veleda da Silva 


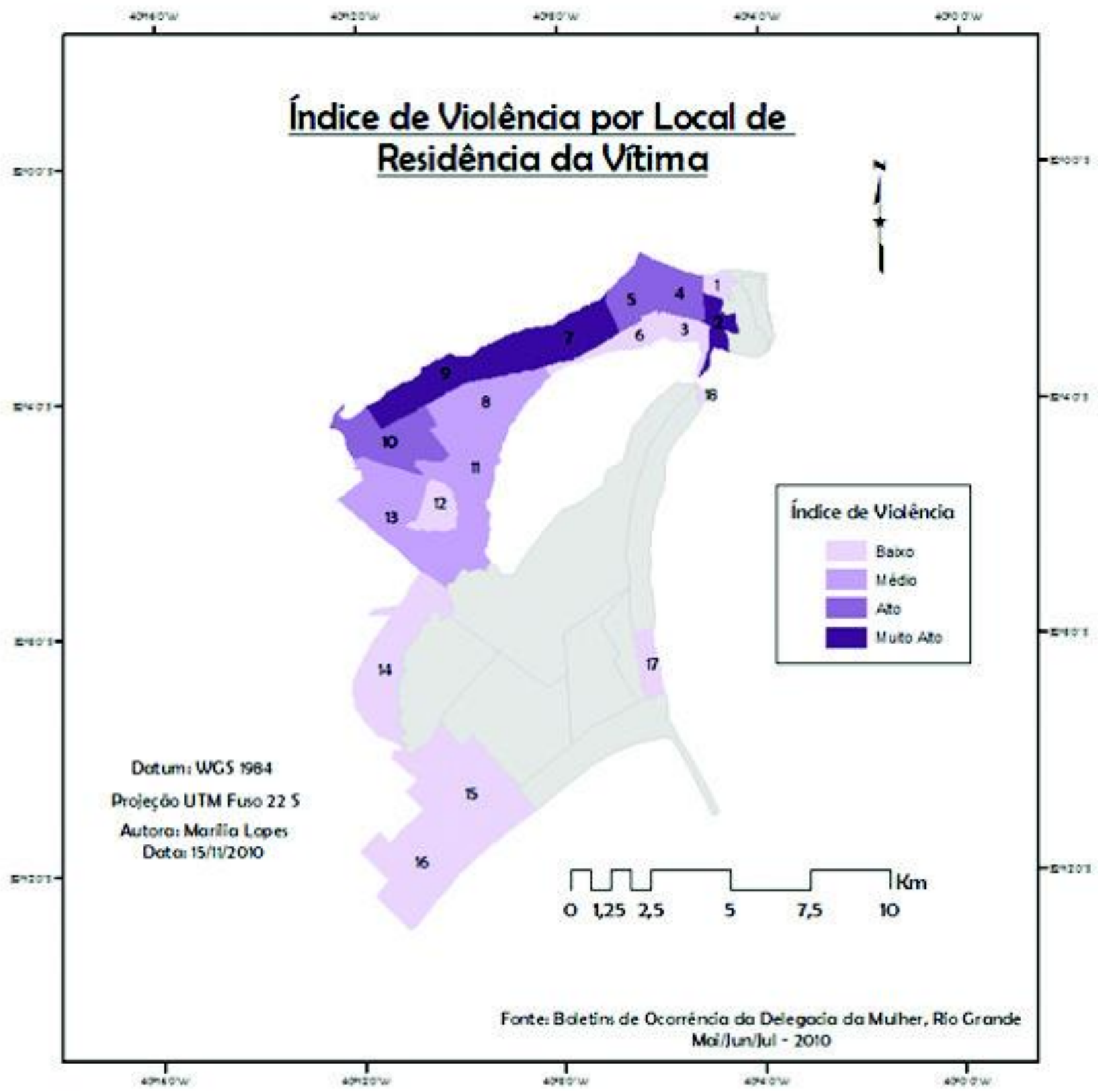

Entendemos que a violência contra mulheres não pode mais ser compreendida como um conflito de ordem familiar e, sim como um problema social que se dá a partir de uma desigualdade de gênero socialmente construída ao longo de séculos. É necessário um esforço conjunto, envolvendo os mais diversos segmentos da sociedade a fim de que esta temática decididamente não seja vista como natural e a paixão não dê mais lugar ao crime.

Tendo como base a breve análise proposta pela pesquisa, compreendemos que, muitas vezes, o espaço do crime não é o mesmo das relações familiares, e a naturalidade com a qual o tema abordado é tanta que, a violência entre o casal não ocorre mais apenas em ambiente familiar, tem ocorrido muitas vezes em locais públicos. $\mathrm{O}$ agressor não se constrange perante os outros, afinal de contas, vivemos uma cultura 
machista que entende que se a mulher está sofrendo agressão é porque 'ela deve ter feito algo para merecer'.

Também foi possível verificar que, a violência de gênero está disseminada por todo o município do Rio Grande e sua tipologia é a mais diversificada possível. Ainda que, grande parte dos registros tenha sido feita por pessoas de baixa escolaridade e por moradoras de localidades com perfil de baixa renda, não podemos inferir que a violência contra as mulheres apresente somente vítimas com essas características. É necessário considerar que com maior autonomia é mais fácil sair de uma relação violenta. Mesmo neste pequeno recorte temporal encontramos vítimas de todas as idades, cores e de diferentes níveis de escolaridade.

O medo, a discriminação por parte da sociedade e principalmente a falta de autonomia são barreiras que impedem algumas mulheres de procurarem os recursos de proteção. A Lei Maria da Penha evidentemente constitui uma importante ferramenta no combate a violência contra as mulheres, justamente por apresentar medidas que possibilitem amparo para quem está em situação de violência. Entretanto, é muito importante divulgar os direitos das mulheres, assim como os mecanismos que já existem a nível local para garantir sua proteção. Esse enfrentamento necessita da ação articulada entre diversos setores como saúde, principalmente através da implementação da Notificação Compulsória nos casos de violência contra as mulheres, educação e assistência social, apenas para citar alguns.

Apesar de sabermos que a violência contra as mulheres ocorre cotidianamente em diversos lares brasileiros, ainda não se tem estatísticas sistemáticas e oficiais que nos mostre o cenário atual desse fenômeno. Entretanto, está previsto na LMP a criação de um Sistema Nacional de Dados e Estatísticas sobre Violência Doméstica e Familiar Contra as Mulheres. Com isso teremos dados mais precisos e de diferentes áreas, que ao serem cruzados nos permitirão enxergar com maior clareza a realidade das mulheres brasileiras.

Em Rio Grande, alinhada a Delegacia Especializada de Atendimento à Mulher, já existe uma Casa Abrigo, para onde as Mulheres em situação de violência e seus filhos menores são levados, em casos mais graves. Entendemos que há comprometimento por parte do Estado, entretanto, para que tenhamos diminuição e/ou erradicação desses crimes precisamos implementar políticas que promovam equidade entre homens e mulheres, visando quebrar o muro de preconceito no qual grande parte da sociedade ainda está envolto. É necessário que se compreenda e se aceite as diferenças entre os sexos para que elas deixem de se transformar em desigualdades e violências.

1 O texto é parte do Trabalho de Conclusão de Curso de Geografia Bacharelado da Universidade do Rio Grande (FURG) de mesmo nome, em 2010.

2 A lei 11.340/06 foi batizada assim em reconhecimento à luta por justiça de Maria da Penha, vítima de repetidas agressões e de duas tentativas de homicídio por parte do marido, sendo que uma delas a deixou paraplégica: ela levou um tiro enquanto dormia. Em 2001, após 18 anos de omissão do Estado Brasileiro, a Comissão Interamericana de Direitos Humanos da Organização dos Estados Americanos (OEA) acatou as denúncias feitas em 1998 pelo Centro para a Justiça e o Direito Internacional (CEJIL/Brasil) e pelo Comitê Latino-Americano e do Caribe para a Defesa dos Direitos da Mulher e responsabilizou o Estado brasileiro por omissão e negligência em relação à violência doméstica, recomendando várias medidas no caso específico de Maria da Penha e a revisão das políticas públicas vigentes no âmbito da violência contra as mulheres.

3 O trimestre escolhido deve-se ao fato de que a partir do mês de maio, os BO's foram organizados de acordo com o mês de ocorrência dos registros.

$4 \quad$ SR - Sem Registro.

5 Utilizamos o critério do IBGE para classificar a cor da pele, portanto, agrupamos na cor parda os registros que utilizavam as designações mulata(o) e sarara.

$6 \quad \mathrm{SR}=$ Sem Registro

$7 \quad \mathrm{SR}=$ Sem Registro

8 Esta malha contém apenas os setores censitários urbanos, disponibilizados por municípios. Já os setores censitários rurais são disponibilizados apenas por unidades federativas. Dessa forma, optamos por espacializar a violência contra as mulheres somente na cidade do Rio Grande (Primeiro Distrito) não considerando os dados das áreas rurais.

9 O setor censitário é a menor unidade territorial, com limites físicos identificáveis em campo com dimensão adequada à operação de pesquisas e cujo conjunto esgota a totalidade do Território Nacional (IBGE, 2000). 
10 O principal critério comparativo foi a renda média do responsável pelos setores, a fim de explicitar a relação entre as áreas consideradas mais nobres e a violência doméstica contra a mulher. Foram utilizados dados do GeoSnic - Ministério das Cidades (ver http://www.cidades.gov.br/)

\section{Referências}

AGENDE - AÇÕES EM GÊNERO CIDADANIA E DESENVOLVIMENTO. 10 anos da adoção da Convenção Interamericana para Prevenir, Punir e Erradicar a Violência contra a Mulher - Convenção de Belém do Pará. Brasília, 2004. Disponível em: $<$ http://www.agende.org.br/> Acesso em 20 janeiro de 2012.

ARAÚJO, Maria de F.; MARTINS, Edna J. S. e SANTOS, Ana L.. Violência de gênero e violência contra a mulher. In: ARAÚJO; Maria de F. e MATTIOLI, Olga C. (Orgs). Gênero e violência. São Paulo: Arte \& Ciência, 2004, p.17 - 36.

AZEVEDO, Maria. A. Mulheres espancadas: a violência denunciada. São Paulo: Cortez, 1985.

BRASIL. Constituição, 1988.

BRASIL. Lei 11.340 de 7 de agosto de 2006. 2006

IBOPE/INSTITUTO AVON. Percepções e reações da sociedade sobre a violência contra a mulher. 2009 .

IBOPE/INSTITUTO PATRÍCIA GALVÃO. Percepções e Reações da Sociedade sobre a Violência contra a Mulher. 2006.

INSTITUTO BRASILEIRO DE GEOGRAFIA E ESTATÍSTICA (IBGE). Censo Demográfico. Disponível em <http://www.ibge.gov.br>. Acesso em 20 de janeiro de . 2012.

INSTITUTO BRASILEIRO DE GEOGRAFIA E ESTATÍSTICA (IBGE). Notas Metodológicas. Disponível em <http://www.ibge.gov.br>. Acesso em dez. 2011.

LOPES, Marília C. Da Paixão ao crime: uma espacialização da violência contra as mulheres em Rio Grande. Trabalho de Conclusão de Curso em Geografia Bacharelado. Rio Grande, FURG, 2010.

MEDEIROS, Mércia C. Unidos contra a violência. In:
CASTILLO-MARTIN, Márcia; OLIVEIRA, Suely de (Org.). Marcadas a ferro: Violência contra a mulher. Uma visão multidisciplinar. Brasília: Secretaria Especial de Políticas para as Mulheres, 2005, p. $100-104$.

MINISTÉRIO DAS CIDADES. Disponível em $<$ http://www.cidades.gov.br/>. Acesso em novembro de 2010.

RIO GRANDE DO SUL. Decreto $n^{\circ} 46.540$ de 6 de agosto de 2009. 2009.

RIO GRANDE. Lei n⿳ 5.312 de 28 de junho de 1999. 1999.

RIO GRANDE. Lei $\mathbf{n}^{\mathbf{0}} \mathbf{5 . 9 9 2}$ de 26 de agosto de 2004. 2004.

SAFFIOTI, Heleieth. Já se mete a colher em briga de marido e mulher. São Paulo em Perspectiva. v. 13, n. 4, p. $82-91,1999$.

SAFFIOTI, Heleieth. Contribuições feministas para o estudo da violência de gênero. Cadernos Pagu, n. 16, p. $115-136,2001$.

SECRETARIA ESPECIAL DE POLÍTICAS PARA AS MULHERES. Com todas as mulheres, por todos os seus direitos. Brasília: 2010.

SECRETARIA ESPECIAL DE POLÍTICAS PARA AS MULHERES. Lei Maria da Penha - Lei no 11.340 de 7 de agosto de 2006. Coíbe a violência doméstica e familiar contra a mulher. Brasília: 2006.

TELES, Maria Amélia; MELO, Mônica. O que é Violência contra a Mulher. São Paulo: Brasiliense, 2003.

VELEDA DA SILVA, Susana Maria. A perspectiva feminista na geografia brasileira. In: SILVA, Joseli Maria (Org.). Geografias Subversivas: discursos sobre espaço, gênero e sexualidades. Ponta Grossa: Toda Palavra, 2009, p. 301-311. 